\title{
Dynamics of meiobenthic copepod populations: a long-term study (1973-1983)*
}

\author{
Bruce C. Coull \& Bettye W. Dudley \\ Belle W. Baruch Institute for Marine Biology and Coastal Research, Department of Biology, and Marine Science Program, \\ University of South Carolina, Columbia, South Carolina 29208, USA
}

\begin{abstract}
Eleven years of monthly (or fortnightly) monitoring of meiobenthic copepods at 2 subtidal estuarine sites (sand and mud) in South Carolina, USA indicates that the 2 communities are controlled by different mechanisms. The mud community is distinctly seasonal, whereas at the sand site seasonality is not pronounced. Sand-site copepods have been declining over the $11 \mathrm{yr}$ and their number of species has decreased at the rate of about $1 \mathrm{yr}^{-1}$. There has been no significant change at the mud site. The decrease in copepod species at the sand site was correlated with a concommitant decrease in sediment median grain size and sorting. There were no significant long-term abundance cycles at either site. Twelve mo was the maximum statistically reliable periodicity recorded at either site; although some of the sand species had no periodicity. It appears that meiobenthic copepods respond primarily to short-term seasonal events. Thus, a 2 yr monitoring period should be sufficient to determine meiobenthic copepod seasonality patterns.
\end{abstract}

\section{INTRODUCTION}

Temporal studies of marine meiobenthos have traditionally been directed toward describing trends in abundance variability at the major taxon level (e.g. nematode, copepod). When species composition and population life history stages (e.g. males, females, juveniles, ) are included, the studies tend to be of short duration $(<2$ yr) or limited to 1 or a few closely clustered points in time. The seasonal pattern(s) discerned in such short interval studies are typically inferred to be 'the' seasonal pattern(s) of the species in question. Except for the 7 yr data set of Heip (1980) and Herman \& Heip (1983) and earlier reports on 2 to 3 yr of the present data set (Coull \& Vernberg 1975, Coull \& Fleeger 1977) we are unaware of meiofaunal studies where continuous species and life history information have been collected for longer periods.

We report on 11 yr (1973-1983) of continuous sampling of the meiobenthic copepod taxocene at 2 subtidal sites (sand and mud) in a Southeastern United States salt marsh complex. Copepods (including nauplii)

\footnotetext{
- Contribution No. 576 from the Belle W. Baruch Institute for Marine Biology and Coastal Research
}

numerically comprise 17 and $13 \%$ of the total meiofauna at the mud and sand site, respectively, and were second and third in abundance to nematodes and gastrotrichs at these sites (Coull 1985b). The present study examines copepod species abundance patterns over time and the inherent community patterns within these copepod taxocenes.

This research was conducted at the Belle W. Baruch Institute for Marine Biology and Coastal Research's North Inlet Estuarine system, the only marine/ estuarine site in the National Science Foundation's Long-Term Ecological Research network. North Inlet is a natural undisturbed ecosystem maintained for conservation and research; thus an ideal setting to determine natural changes, fluctuations and trends in populations. The questions central to this research are: How do natural populations fluctuate, i.e. is there continuity over time in abundance and/or species abundance? What factors control the changes or the continuity? Are there different seasonal or long-term patterns in sand and mud assemblages separated by less than $2 \mathrm{~km}$ ? Does ovigerous female abundance precede juvenile abundance, precede total abundance, etc., and how long must one sample to discern consistent seasonal patterns in meiobenthic populations? 


\section{METHODS AND MATERIALS}

Field and laboratory. Details of meiofauna sampling/ extraction and collection of the associated physical data are presented in Coull (1985b); we will not reiterate them here. Suffice it to say that sampling, with 2, 3 or 4 replicates on each sampling date, was performed in standard meiofaunal fashion. Samples were taken monthly 1973-80 and fortnightly 1981-83. Mud sample extraction was by Ludox centrifugation (deJonge \& Boumann 1977); sand sample extraction by shakingdecantation (Wieser 1960).

Each copepod was removed identified to species, sexed, assessed as to status of eggs and defined as a juvenile or an adult. Prior to October 1975 all copepods from each of 4 replicates were placed in the same container to await identification. Thus between replicate variance could not be calculated for species data prior to that date. Starting October 1975 species were identified by replicate. All copepod data are presented as number $10 \mathrm{~cm}^{-2}$ following the admonishment of Hicks \& Coull (1983, p. 83) to avoid percentage data.

Data analyses. All data have been stored on the University of South Carolina's IBM 3801 computer as SAS (SAS Institute, 1982) data sets. Autoregression analysis was used to determine whether the abundance of an individual species was increasing or decreasing through time. Autoregression was used because, as with most time series data, sampling dates were autocorrelated and the error term was not independent across time. Other statistical analyses are as outlined in Coull (1985b).

\section{RESULTS}

Details of the physical factors are provided in Coull (1985b). Briefly, temperature and salinity varied seasonally at both sites with maximum temperatures in August and minimum salinities in late winter/early spring (see Coull 1985b, Fig. 2). Neither temperature nor salinity was significantly different among years. At the mud site sediment, median grain size (mgs) ranged from 29 to $63 \mu \mathrm{m}$; sorting coefficient $\left(S_{0}\right)$ from 0.95 to $2.50(\overline{\mathrm{x}}=1.46)$ and percent silt-clay (\% SC) from 59 to $69 \%$. There were no significant between year differences in any of these 3 parameters at the mud site. At the sand site, however, both median grain size and sorting coefficient decreased significantly (ANOVA, $p=0.001$ and $p=0.0002$ respectively) between the period 1973-79 and 1983. Median grain size decreased by $\sim 93 \mu \mathrm{m}$ and sorting coefficient by 0.22 units. See Coull (1985b) for details.

Seventy-three copepod species were identified from the 2 sites over the $11 \mathrm{yr} 47$ at the mud site and 56 at the sand site (Tables 1 \& 2). The mean number of copepod species per sampling date ranged from 2 to 15 at the mud site and 1 to 16 at the sand site. The mean number of species during the entire 11 yr was 6.9 at the mud site and 5.7 at the sand site. There was no significant difference between months in the number of species at either site (1-way ANOVA: mud, df $=11$, $\mathrm{F}=1.21, \mathrm{p}=0.24 ;$ sand $, \mathrm{df}=11, \mathrm{~F}=1.79, \mathrm{p}=0.06)$ nor was there any significant difference between years at the mud site ( $\mathrm{df}=10, \mathrm{~F}=1.55, \mathrm{p}=0.12$ ). There was a significant difference between years in the number of species ( $\mathrm{df}=10, \mathrm{~F}=3.64, \mathrm{p} \leq 0.0001$ ) at the sand site. Scheffé multiple comparisons indicate that there were significantly fewer species in 1981 and 1983 than in all other years at the sand site. Fig. 1 illustrates the yearly number of species at the sand site and their substantial decline over the study period.

The 6 most abundant species at each site were chosen for more detailed analysis. At the mud site these species comprised $88.5 \%$ of all copepods collected (Table 1) and at the sand site made up $84.4 \%$ (Table 2).

We have plotted the mean abundance of total individuals, females, ovigerous females, and copepodites for Leptastacus macronyx, at the sand site for each sampling (Fig. 2) and in Fig. 3 we have plotted similar data for Halicyclops coulli from the mud site. We selected these species to plot the 'every-point' data because L. macronyx is the dominant sand site species (Table 2) and demonstrates a pattern of long-term decline common to all the interstitial species at the sand site. $H$. coulli was chosen because it is a species with 1 repeatable abundance peak per year (Fig. 3). Similar plots for the other 5 most abundant species at each site, while providing the mean $\pm S E$ for each sampling when replicates were maintained, are 'busy' and difficult to interpret. Thus, we have plotted the monthly means (i.e. the means of 11 January's, 11 February's, etc.) and the yearly means (i.e. mean for 1973 , 1974 , etc.) for the other 5 species at each site. In these plots (Fig. 4 \& 5), only the total copepods values are plotted. Life history stages were not included because in every case the abundance patterns of the life history stages (females, ovigerous females, copepodites) were coincident in time with the 'total' abundance patterns. $A$. priori we expected time to be offset, e.g. first a peak (or lull) in ovigerous females, then copepodites, then totals but this was not the case when the every-point data for each category were overlain.

Each of the 6 most abundant species at the mud site (Fig. $3 \& 4$ ) varied seasonally (Months 1 to $3=$ winter, Months 4 to $6=$ spring, Months 7 to $9=$ summer, Months 10 to 12 = autumn; 1 -way ANOVA: season/ abundance, $p \leq 0.0001$ for all 6 species). Scheffé com- 
Table 1. Eleven yr (Jan 1973 to Dec 1983) mean abundance of each copepod species collected at the mud site. Summary statistics are not provided for species which had a mean $11-\mathrm{yr}$ total abundance of $<0.1$ ind $10 \mathrm{~cm}^{-2}$. All values (columns) - except for \% abundance, SD of mean and ratio females/males - given as mean abundance $10 \mathrm{~cm}^{-2}$

\begin{tabular}{|c|c|c|c|c|c|c|c|c|}
\hline Species & $\begin{array}{c}\% \text { of } \\
\text { Total } \\
\text { copepods }\end{array}$ & $\begin{array}{l}\text { Mean } \\
\text { abun- } \\
\text { dance }\end{array}$ & Range & $\begin{array}{c}\text { SD } \\
\text { of } \\
\text { Mean }\end{array}$ & Qq & $\begin{array}{c}\text { Ovigerous } \\
\$ Q\end{array}$ & $\begin{array}{l}\text { Cope- } \\
\text { podites }\end{array}$ & $\begin{array}{c}\text { Ratio } \\
\text { female } \\
\text { males }\end{array}$ \\
\hline Pseudobradya pulchella Sars & 18.0 & 23.2 & $0-406$ & 48.9 & 9.4 & 2.6 & 10.9 & 3.2 \\
\hline Microarthridion littorale (Poppe) & 17.9 & 23.0 & $0-258$ & 30.9 & 10.4 & 3.7 & 8.7 & 2.7 \\
\hline Halicyclops coulli Herbst & 16.2 & 20.8 & $0-379$ & 34,6 & 10.0 & 3.1 & 6.6 & 2.4 \\
\hline Enhydrosoma propinquum (Brady) & 12.9 & 16.7 & $0-195$ & 27.2 & 9.0 & 3.3 & 3.0 & 1.9 \\
\hline Paronychocamptus wilsoni (Coull) & 12.9 & 16.7 & $0-406$ & 38.1 & 7.8 & 3.7 & 5.5 & 2.4 \\
\hline Halectinosoma winonae Coull & 10.6 & 13.8 & $0-244$ & 28.6 & 6.5 & 0.8 & 6.4 & 6.8 \\
\hline Scottolana canadensis (Wilson) & 3.4 & 4.4 & $0-97$ & 12.7 & 1.7 & 0.4 & 1.5 & 1.4 \\
\hline Enhydrosoma baruchi Coul & 1.9 & 2.5 & $0-44$ & 5.1 & 1.7 & 0.2 & 0.4 & 4.0 \\
\hline Zausodes arenicolus Wilson & 0.9 & 1.2 & $0-28$ & 3.2 & 0.8 & 0.01 & 0.2 & 4.4 \\
\hline Halectinosoma sp. 2 & 0.9 & 1.2 & $0-38$ & 4.3 & 0.5 & 0.8 & 0.6 & 7.6 \\
\hline Diarthrodes aegidius (Brian) & 0.8 & 1.1 & $0-62$ & 4.6 & 0.6 & 0.02 & 0.3 & 2.8 \\
\hline Cyclopoid sp. 2 & 0.7 & 0.9 & $0-120$ & 6.6 & 0.5 & 0.1 & 0.2 & 4.9 \\
\hline Nannopus palustris Brady & 0.5 & 0.6 & $0-13$ & 1.5 & 0.4 & 0.04 & 0.1 & 4.8 \\
\hline Harpacticus sp. & 0.3 & 0.4 & $0-56$ & 3.3 & 0.1 & 0.02 & 0.09 & 0.8 \\
\hline Cyclopoid sp. 3 & 0.2 & 0.3 & $0-7$ & 1.0 & 0.2 & 0.03 & 0.04 & 6.4 \\
\hline Clymenestra rostrata (Brady) & 0.2 & 0.2 & $0-5$ & 2.1 & 0.1 & 0.01 & 0.08 & 4.6 \\
\hline Stenhelia (D) bifidia Coull & 0.2 & 0.2 & $0-\quad 2$ & 0.1 & 0.1 & 0.01 & 0.04 & 18.5 \\
\hline Mesochra pygmaea (Claus) & 0.2 & 0.2 & $0-13$ & 0.9 & 0.1 & 0.01 & 0.02 & 2.7 \\
\hline Longipedia americana Wells & 0.1 & 0.1 & $0-11$ & 0.8 & 0.05 & 0 & 0 & 6.2 \\
\hline Ameira sp. & 0.1 & 0.1 & $0-6$ & 0.6 & 0.09 & 0.05 & 0 & 3.4 \\
\hline Nitocra affinis Gurney & 0.1 & 0.1 & $0-17$ & 1.1 & 0.09 & 0 & 0.02 & 5.4 \\
\hline Thompsonula hyaenae (Thompson) & 0.1 & 0.1 & $0-11$ & 0.8 & 0.09 & 0.01 & 0.01 & 8.5 \\
\hline \multicolumn{9}{|c|}{ All following species had mean abundances of $<0.1$ ind $10 \mathrm{~cm}^{-2}$} \\
\hline Metis holothuriae (Edwards) & \multicolumn{4}{|c|}{ Nitocra sp. } & \multicolumn{4}{|c|}{ Eutepina acutifrons (Dana) } \\
\hline Laophonte cornuta (Philippi) & \multicolumn{4}{|c|}{ Stenhelia $(D)$ sp. } & \multicolumn{3}{|c|}{ Laophontidae sp. } & \\
\hline Cletoididae sp. & \multicolumn{4}{|c|}{ Amphiascus sp. } & \multicolumn{3}{|c|}{ Altheutha sp. } & \\
\hline Heteropsyllus nunni Coull & \multicolumn{2}{|c|}{ Tegastes $\mathrm{sp}$} & & & \multicolumn{3}{|c|}{ Tryphoema sp. } & \\
\hline Quinquelaophonte capillata (Wilson) & \multicolumn{4}{|c|}{ Stenhelia (D) normani Monard } & \multicolumn{3}{|c|}{ Rhizothrix sp. } & \\
\hline Leptocaris mangalis Por & \multicolumn{4}{|c|}{ Amphiascopsis cinctus (Claus) } & \multicolumn{3}{|c|}{ Phyllodopsyllus sp. } & \\
\hline Onychocamptus sp. & \multicolumn{4}{|c|}{ Robertsonia propinquum (Scott) } & \multicolumn{3}{|c|}{ Leptastacus macronyx (Scott) } & \\
\hline Tisbe sp. & \multicolumn{4}{|c|}{ Diagoniceps bocki Lang } & \multicolumn{3}{|c|}{ Diosaccidae sp. } & \\
\hline
\end{tabular}

Fig. 1. Number of copepod species at sand site over the $11 \mathrm{yr}$. Note decrease in number of species

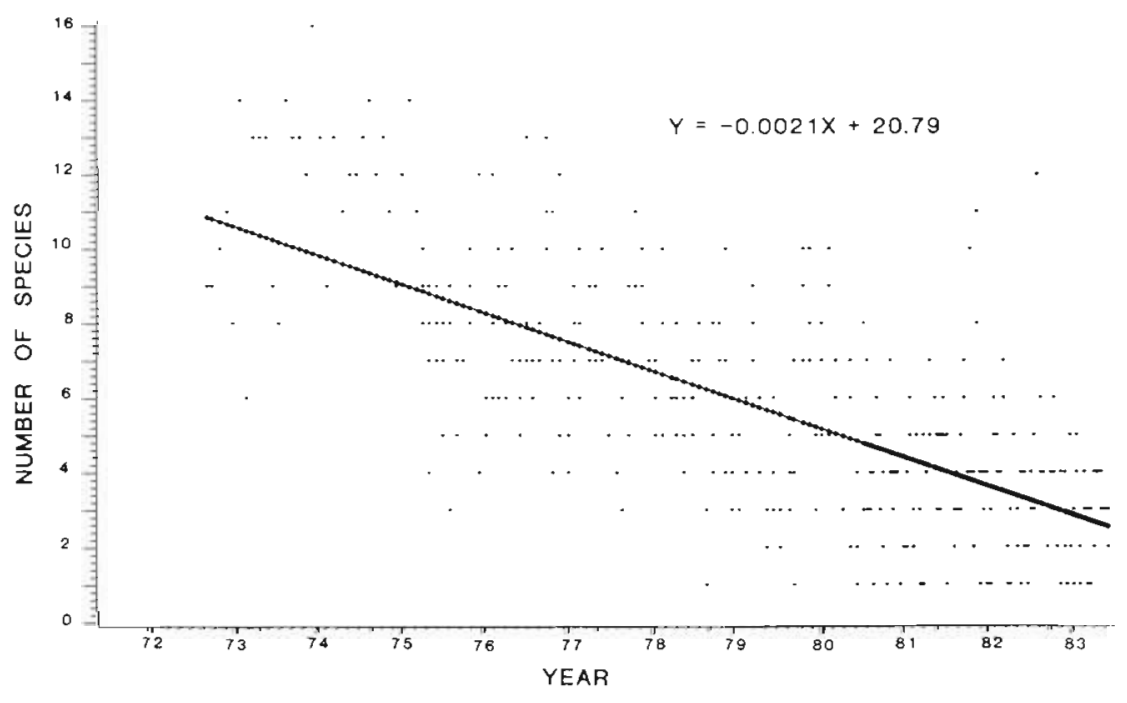


Table 2. Eleven yr (Jan 1973 to Dec 1983) mean abundance of each copepod species collected at the sand site. Summary statistics are not provided for species which had a mean 11 -yr total abundance of $<0.1$ ind $10 \mathrm{~cm}^{-2}$. All values (columns) - except for \% abundance, SD of mean, and female/male ratio - are given as mean abundance $10 \mathrm{~cm}^{-2}$

\begin{tabular}{|c|c|c|c|c|c|c|c|c|}
\hline Species & $\begin{array}{c}\% \text { of } \\
\text { Total } \\
\text { copepods }\end{array}$ & $\begin{array}{l}\text { Mean } \\
\text { abun- } \\
\text { dance }\end{array}$ & Range & $\begin{array}{c}\text { SD } \\
\text { of } \\
\text { mean }\end{array}$ & $\varphi q$ & $\begin{array}{l}\text { Ovige- } \\
\text { rous } \$ Q\end{array}$ & $\begin{array}{l}\text { Copepo- } \\
\text { dites }\end{array}$ & $\begin{array}{c}\text { Ratio } \\
\text { female/ } \\
\text { males }\end{array}$ \\
\hline Leptastacus macronyx (Scott) & 39.9 & 43.9 & $0-699$ & 86.1 & 22.4 & 6.3 & 5.9 & 1.4 \\
\hline Thompsonula hyaenae (Thompson) & 13.9 & 15.4 & $0-991$ & 57.3 & 5.0 & 1.4 & 6.3 & 1.2 \\
\hline Kliopsyllus constrictus (Nicholls) & 9.6 & 10.6 & $0-359$ & 29.8 & 5.9 & 1.8 & 1.0 & 1.6 \\
\hline Arenostella spinicauda Wilson & 8.7 & 9.6 & $0-220$ & 20.6 & 7.4 & 2.0 & 1.1 & 7.2 \\
\hline Apodopsyllus unguiformis Coull \& Hogue & 8.7 & 8.4 & $0-410$ & 27.9 & 4.2 & 0.8 & 1.1 & 1.3 \\
\hline Halectinosoma winonae Coull & 4.7 & 5.1 & $0-105$ & 11.6 & 3.7 & 0.6 & 0.01 & 4.6 \\
\hline Protosammotopa wilsoni (Wells) & 3.4 & 3.7 & $0-90$ & 7.8 & 1.5 & 0.7 & 0.9 & 1.1 \\
\hline Ameira parvula (Claus) & 2.9 & 3.2 & $0-257$ & 16.4 & 1.7 & 0.5 & 0.4 & 1.5 \\
\hline Hastigerella leptoderma (Klie) & 2.6 & 2.9 & $0-140$ & 10.6 & 2.2 & 0.3 & 0.3 & 5.7 \\
\hline Zausodes arenicolus Wilson & 1.3 & 1.4 & $0-60$ & 5.2 & 0.7 & 0.01 & 0.2 & 1.6 \\
\hline Heteropsyllus nunni Coull & 1.1 & 1.2 & $0-47$ & 4.3 & 0.6 & 0.2 & 0.2 & 1.6 \\
\hline Paronychocamptus wilsoni (Coull) & 0.8 & 0.8 & $0-21$ & 3.2 & 0.5 & 0.2 & 0.1 & 2.5 \\
\hline Pseudobradya pulchella Sars & 0.7 & 0.8 & $0-79$ & 4.8 & 0.5 & 0.03 & 0.2 & 1.9 \\
\hline Laophonte cornuta Philippi & 0.3 & 0.3 & $0-15$ & 1.3 & 0.2 & 0.03 & 0.03 & 6.4 \\
\hline Arenopontia arenardia (Pennak) & 0.3 & 0.3 & $0-8$ & 1.2 & 0.2 & 0.04 & 0.01 & 3.2 \\
\hline Halicyclops coulli Herbst & 0.3 & 0.3 & $0-14$ & 1.6 & 0.2 & 0.02 & 0.01 & 5.8 \\
\hline Mesochra pygmaea (Claus) & 0.2 & 0.2 & $0-17$ & 1.3 & 0.1 & 0.02 & 0.02 & 3.6 \\
\hline Diathrodes aegidius (Brian) & 0.1 & 0.1 & $0-8$ & 0.7 & 0.1 & 0 & 0.02 & 6.8 \\
\hline Enhydrosoma propinquum (Brady) & 0.1 & 0.1 & $0-\quad 1$ & 0.8 & 0.05 & 0 & 0.05 & 1.6 \\
\hline Harpacticus sp. & 0.1 & 0.1 & $0-16$ & 1.1 & 0.09 & 0.04 & 0.01 & 4.9 \\
\hline Rhizothrix gracilis (Scott) & 0.1 & 0.1 & $0-12$ & 0.8 & 0.09 & 0.04 & 0 & 4.9 \\
\hline Longipedia americana Wells & 0.1 & 0.1 & $0-12$ & 0.8 & 0.08 & 0 & 0.01 & 5.1 \\
\hline Microarthridion littorale (Poppe) & 0.1 & 0.1 & $0-12$ & 0.7 & 0.03 & 0.02 & 0.1 & 1.8 \\
\hline Leptopontia curvicaudata (Scott) & 0.1 & 0.1 & $0-7$ & 0.6 & 0.09 & 0.03 & 0 & 8.5 \\
\hline Rhizothrix sp. & 0.1 & 0.1 & $0-5$ & 0.6 & 0.07 & 0.03 & 0.02 & 0 \\
\hline Stenhelia $(D)$ bifidia Coull & 0.1 & 0.1 & $0-17$ & 0.9 & 0.05 & 0 & 0.01 & 0 \\
\hline Stenocaris sp. & 0.1 & 0.1 & $0-4$ & 0.4 & 0.05 & 0.02 & 0.01 & 0 \\
\hline Cyclopoidsp. & 0.1 & 0.1 & $0-14$ & 0.8 & 0.06 & 0.04 & 0 & 0 \\
\hline Halectinosoma sp. & 0.1 & 0.1 & $0-10$ & 0.6 & 0.04 & 0.01 & 0.01 & 2.6 \\
\hline \multicolumn{9}{|c|}{ All following species had mean abundances of $<0.1$ ind $10 \mathrm{~cm}^{-2}$} \\
\hline Enhydrosoma baruchi Coull & \multicolumn{4}{|c|}{ Cletoididaesp. } & \multicolumn{4}{|c|}{ Robertsonia propinquum (Scott) } \\
\hline Tryphoema sp. & \multicolumn{4}{|c|}{ Nannopus palustris Brady } & \multicolumn{4}{|c|}{ Nitocra affinis Gurney } \\
\hline Scottolana canadensis (Wilson) & \multicolumn{4}{|c|}{ Psyllocamptus sp. } & \multicolumn{4}{|c|}{ Amphiascopsis cinctus (Claus) } \\
\hline Paraleptastacus spinicaudia (T \& A Scott) & \multicolumn{4}{|c|}{ Arenopontia subterranea Kunz } & \multicolumn{4}{|c|}{ Schizoperasp. } \\
\hline Onychocamptus sp. & \multicolumn{4}{|c|}{ Peltidium sp. } & \multicolumn{4}{|c|}{ Leptocaris mangalis Por } \\
\hline Diosaccidaesp. & \multicolumn{4}{|c|}{ Normanellasp. } & \multicolumn{4}{|c|}{ Amphiascussp. } \\
\hline Metis holothuriae (Edwards) & \multicolumn{4}{|c|}{ Scottosyllus pararobertsonia Lang } & \multicolumn{4}{|c|}{ Stenhelia (D) sp. } \\
\hline Phyllopodopsyllus sp. & \multicolumn{4}{|c|}{ Thalestridae sp. } & \multirow{2}{*}{\multicolumn{4}{|c|}{ Paralaophonte congenera (Sars) }} \\
\hline Ameira sp. & \multicolumn{4}{|c|}{ Leptastacus minutus Chappuis } & & & & \\
\hline
\end{tabular}

parisons (Table 3) demonstrated which seasons were different for each species.

At the sand site there were no significant seasonal changes in Leptastacus macronyx (1-way ANOVA: season/abundance, $\mathrm{p}=0.636$ ) or Kliopsyllus constrictus $(\mathrm{p}=0.717)$ (Fig. $2 \& 5$; Table 4). The remaining 4 dominant species, Thompsonula hyaenae, ApodopsylIus unguiformis, Halectinosoma winonae and Arenosetella spinicauda were seasonal (Fig. 5; Table 4). Note that $H$. winonae occurs among the dominant species at both the sand and the mud site (Fig. 4 \& 5), but reaches maximum abundance at different times of the year at each site, autumn in mud; summer in sand (Fig. 4 \& 5; Tables $3 \& 4$ ).

One of the dominant species at the mud site (Halicyclops coulli) and 3 at the sand site (Leptastacus macronyx, Kliopsyllus constrictus, Arenosetella spinicauda) declined significantly in abundance over the $11 \mathrm{yr}$. The autoregression slopes and significance for the 4 species are: $H$. coulli (slope $=-0.050$ 


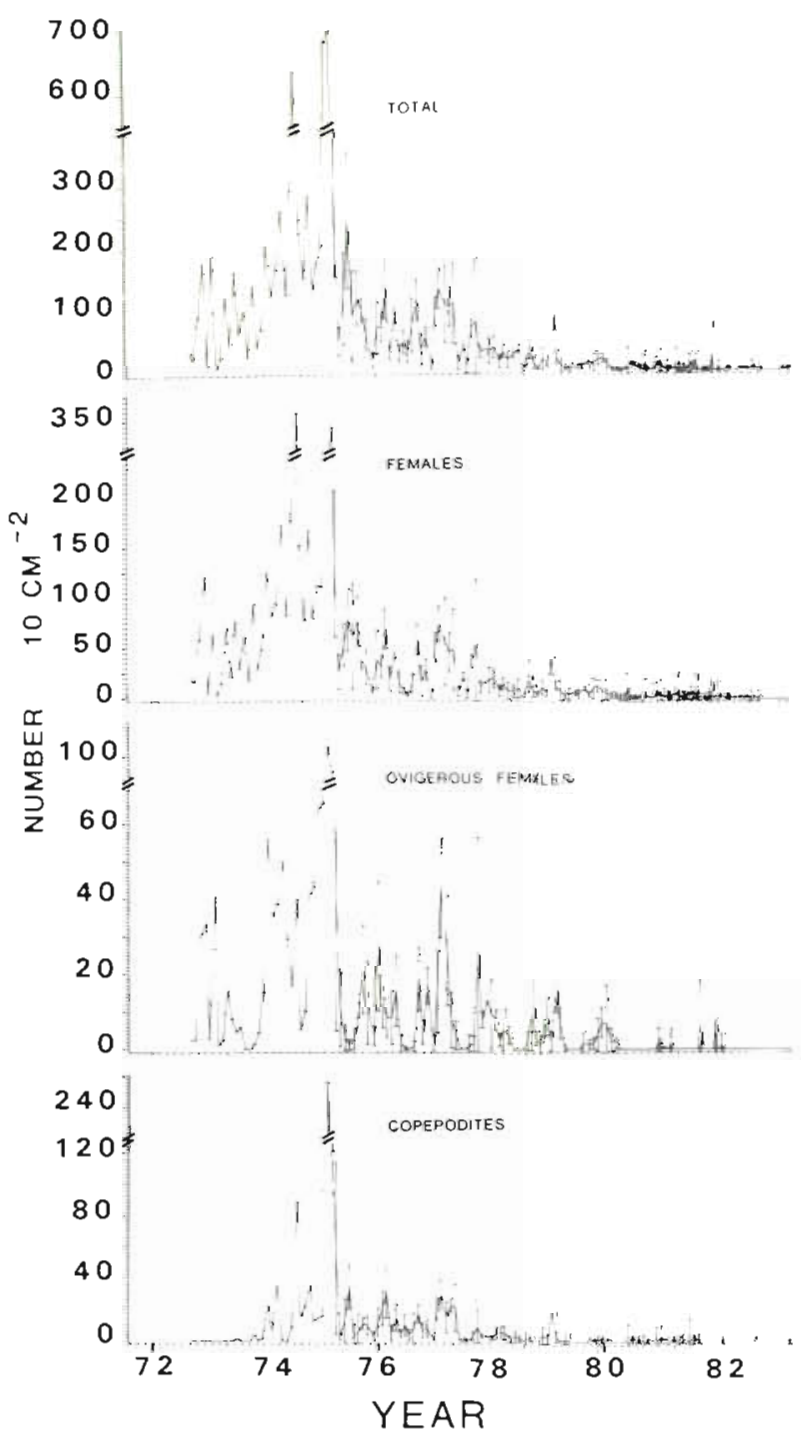

Fig. 2. Leptastacus macronyx. Mean abundance ( \pm SE) of total number, females, ovigerous females, and copepodites for each sampling time at sand site (Jan 1973 to Dec 1983). Year labels, e.g 72,74,76, are placed at yearly midpoints (1 Jul)

$\mathrm{p}=0.013) ; L$. macronyx $($ slope $=-0.047 ; \mathrm{p}=0.006) ;$ $K$. constrictus (slope $=-0.012 ; p=0.009$ ) and $A$. spinicauda (slope $=-0.067$; $\leq 0.001$ ). All 3 declining sand species are interstitial forms as they occupy the spaces between sand grains, whereas 2 of the 3 species that did not decline significantly ( $T$. hyaenae and $H$. winonae) were epibenthic forms which occupy the sediment surface. Apodopsyllus unguiformis (no significant decline) is also an interstitial species.

Time series (spectral) analyses indicated no periodicity of greater than $1 \mathrm{yr}$ in the abundance of the dominant and dwelling species (Fig. 6). Two of the 6 mud species (Pseudobradya pulchella and Halectinosoma winonae) also had cycles at $6 \mathrm{mo}$, as did the

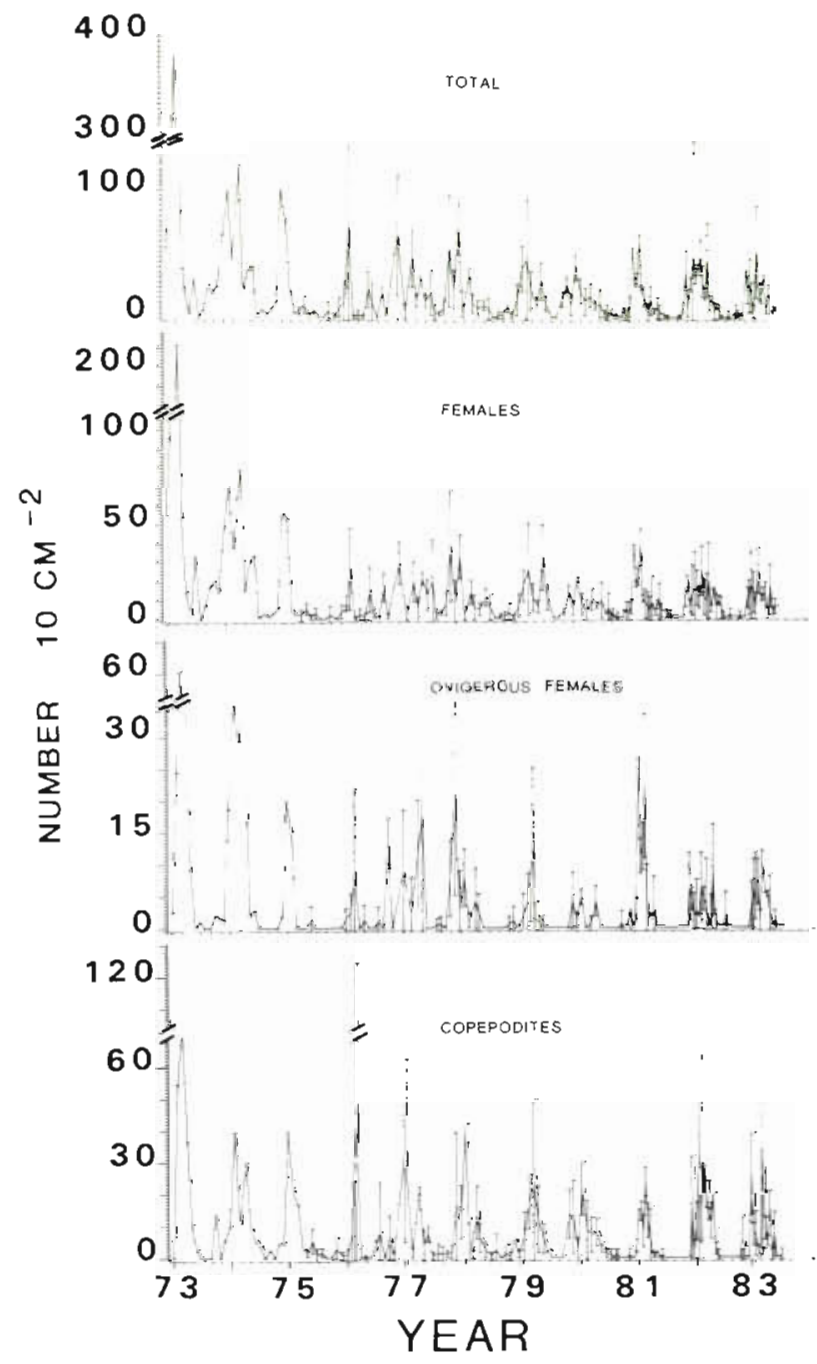

Fig. 3. Halicyclops coulli. Mean abundance $( \pm \mathrm{SE}$ ) of total number, females, ovigerous females, and copepodites for each sampling time at mud site (Jan 1973 to Dec 1983). Year labels, e.g. 73, 75, 77, are placed at yearly midpoints (1 Jul)

abundance of total copepods at the mud site (Coull 1985b).

At the sand site the spectral plots indicated that Apodopsyllus unguiformis and Halectinosoma winonae had major periodicities at $1 \mathrm{yr}$. The other 4 dominant species have spectral density maxima at varying periodicities: Leptastacus macronyx (33 to $66 \mathrm{mo})$, Thompsonula hyaenae $(6,12,33,66 \mathrm{mo})$, Kliopsyllus constrictus (6, $44 \mathrm{mo})$, Arenosetella spinicauda $(6,12,33,44 \mathrm{mo})$ (Fig. 7). The data-set length is $132 \mathrm{mo}$ and the coincidence of spectral density maxima at 66 mo (1/2 the wave length), $44 \mathrm{mo}$ $(1 / 3$ the wave length) or $33 \mathrm{mo}(1 / 4$ the wave) suggested that these supposed 'long term' periodicities may have been harmonics of the total data set, i.e. an interaction between data-set length and analysis procedure. To 


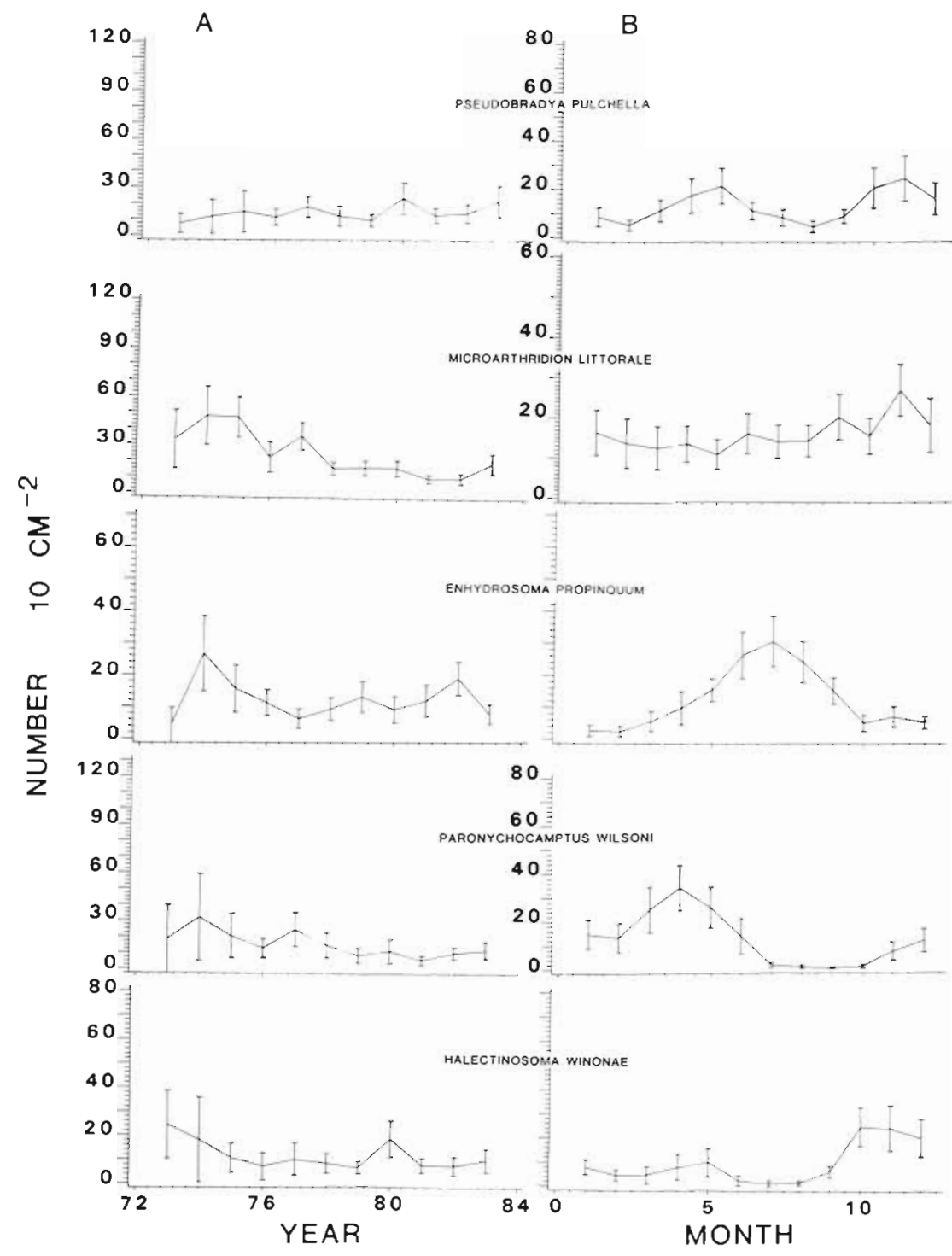

test whether this was an artifact of record length, we ran 96 continuous mo ( 8 yr); 84 continuous mo ( 7 yr); and 72 continuous mo ( 6 yr) of individual abundance data to determine if the supposed 'long-term' cycles were real or a function of the total data-set length (a harmonic). Indeed, in all cases, spectral density maxima were obtained at the predicted harmonic interval with only the 6 mo cycle persisting for Arenosetella spinicauda and Thomsonula hyaenae. All other peaks then were artifacts of the analysis and we could not discern any cycles longer than 1 yr. While we have already demonstrated the distinct seasonality within the mud species and relative lack of distinct seasonality in the sand dwellers (Fig. 2 to 5; Tables 3 \& 4), spectral analysis allows a view of potential longer term periodicities; there appears to be little long-term periodicity at either site. vidually
Fig. 4. (A) Yearly mean total abundances $( \pm \mathrm{SE})$ of the other 5 most abundant copepod species at mud site. (B) Monthly mean abundances ( \pm SE) of 5 species at mud site

\section{DISCUSSION}

\section{Number of species}

The number of species did not change seasonally or over the $11 \mathrm{yr}$ at the mud site, but while there was no seasonal change at the sand site, the number of species decreased over the study period (Fig. 1). This decrease of approximately 1 species per year may well be due to the decreasing trend in total copepod abundance at the sand site concomittant with the lower median grain size and increased sediment sorting (Coull 1985a, b). The finer, better sorted sediments have apparently eliminated the interstitial habitat for Leptastacus macronyx, Kliopsyllus constrictus, Arenosetella spinicauda and other less abundant species not discussed indi- 
Fig. 5. (A) Yearly mean total abundances ( $\pm \mathrm{SE}$ ) of the other 5 most abundant copepod species at sand site. (B) Monthly mean abundances ( $\pm \mathrm{SE}$ ) of 5 species at sand site
A

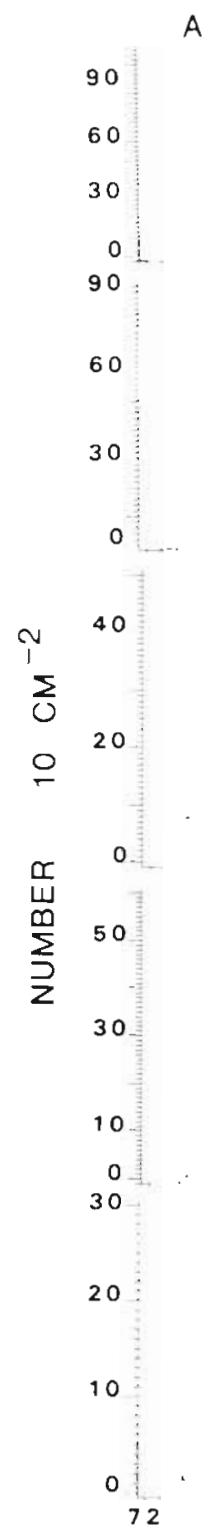

B

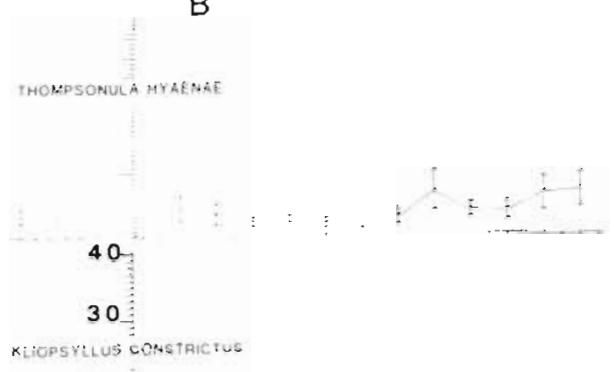

KLOPSYLLS CONSTRICTUS

20

10

0

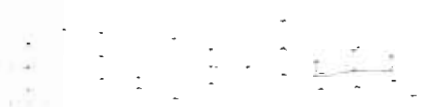

Coull \& Fleeger (1977), utilizing the first $3 \mathrm{yr}$ (1973-75) of this present data set, concluded that the number of species did not change seasonally, or over a $3 \mathrm{yr}$ period, at either site. However, they suggested that the mechanisms controlling diversity constancy were different, i.e. varied microhabitats (= spatial heterogeneity) in sand and distinct seasonal suites of species (temporal separation) in mud. Since that time, decreased grain size and increased sorting $\left(S_{0} \sim 1\right)$ have apparently reduced the sand microhabitat heterogeneity and thus the diversity observed by Coull \& Fleeger (1977). With no sedimentological or apparent physical changes at the mud site, the pattern persists and the seasonal switching of species suites continues to maintain constant species numbers.

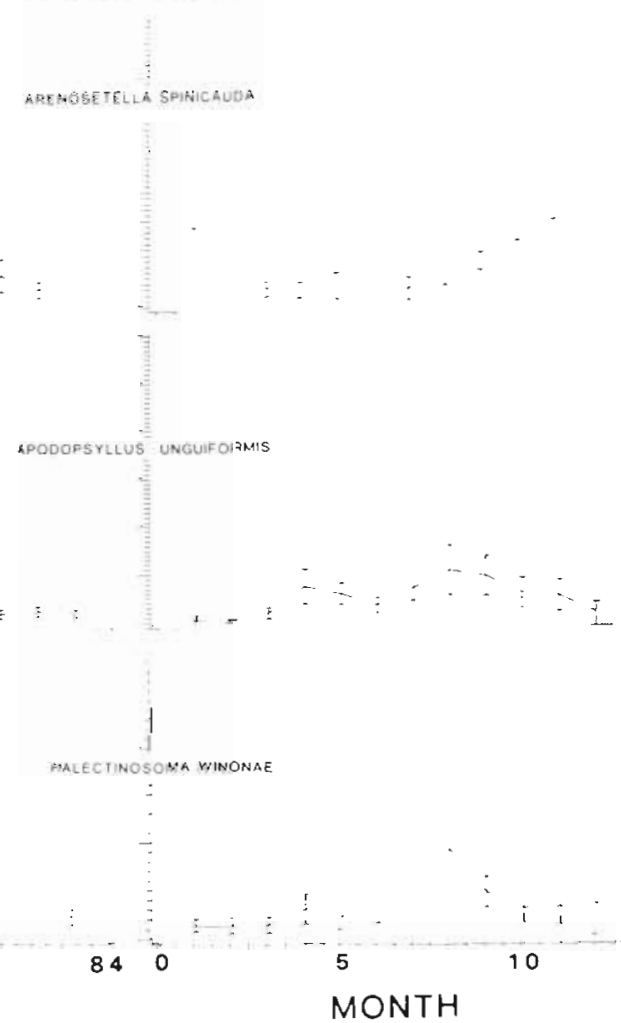

Seasonal abundance

Coull \& Vernberg (1975) reported on seasonal abundance and reproductive patterns of the dominant species at both sites for 28 mo (Sep 1972 to Dec 1974). The thrust of their discussion was directed at whether the dominant species during the $2.3 \mathrm{yr}$ period reproduced continuously or cyclically, as well as observation on the seasonal cycling of abundances. At the mud site the seasonal abundance patterns based on the full 11 yr are the same as reported by Coull \& Vernberg for $2.3 \mathrm{yr}$, with the exception of Pseudobradya pulchella. There have been some nomenclatural changes and additions of species since the Coull \& Vernberg report; Halectinosoma sp. of Coull \& Vernberg is now $H$. 
Table 3. Seasonal rank abundance of the 6 most abundant copepod species at the mud site. Seasons with common underlines are not significantly different in abundance (Scheffé multiple comparison method; experiment wise error rate $p \leqq 0.05$ ). Seasons are W: winter; $S p$ : spring; Su: summer; A: autumn. The 1-way ANOVA, comparing a species abundance and season, indicated there were significant differences between seasons ( $p \leq 0.0001$ in every case)

\begin{tabular}{|lcccc|}
\hline \multicolumn{1}{|c|}{ Species } & \multicolumn{5}{c|}{$\begin{array}{c}\text { Season } \\
\text { (mean abundance } \\
10 \mathrm{~cm}^{-2} \text { for that season) }\end{array}$} \\
\hline Pseudobradya pulchella & $\mathrm{Sp}$ & $\mathrm{A}$ & $\mathrm{W}$ & $\mathrm{Su}$ \\
Microarthridion littorale & $\underline{(42)}$ & $(32)$ & $\underline{(12)}$ & $(7)$ \\
Halicyclops coulli & $\mathrm{A}$ & $\mathrm{W}$ & $\mathrm{Su}$ & $\mathrm{Sp}$ \\
& $\underline{(35)}$ & $\underline{(20)}$ & $(19)$ & $(17)$ \\
Enhydrosoma propinquum & $\mathrm{Su}$ & $\mathrm{Sp}$ & $\mathrm{Au}$ & $\mathrm{W}$ \\
Paronychocamptus wilsoni & $\underline{(45)}$ & $\underline{(17)}$ & $(16)$ & $\underline{(5)}$ \\
& $\mathrm{Su}$ & $\mathrm{Sp}$ & $\mathrm{A}$ & $\mathrm{W}$ \\
Halectinosoma winonae & $\underline{(30)}$ & $(28)$ & $\underline{(7)}$ & $(4)$ \\
& $\mathrm{Sp}$ & $\mathrm{W}$ & $\mathrm{A}$ & $\mathrm{Su}$ \\
& $\underline{(36)}$ & $(26)$ & $\underline{(6)}$ & $(1)$ \\
& $\mathrm{A}$ & $\mathrm{Sp}$ & $\mathrm{W}$ & $\mathrm{Su}$ \\
& $\underline{(35)}$ & $\underline{(7)}$ & $(7)$ & $(4)$ \\
\hline & & & & \\
\hline
\end{tabular}

Table 4. Seasonal rank abundance of the 6 most abundant copepod species at the sand site. Seasons with common underlines are not significantly different in abundance (Scheffé multiple comparison method; experiment wise error rate $\mathrm{p} \leqq 0.05$ ). Seasons are $W$ : winter; Sp: spring; Su: summer; A: autumn. The $p$ value next to the species name is the probability that there are differences between seasons (from the 1-way ANOVA comparing abundance and season)

\begin{tabular}{|c|c|c|c|c|}
\hline Species $(p>F)$ & \multicolumn{4}{|c|}{$\begin{array}{c}\text { Season } \\
\text { (mean abundance } \\
10 \mathrm{~cm}^{-2} \text { for that season) }\end{array}$} \\
\hline Leptastacus macronyx & $\begin{array}{c}\mathrm{Su} \\
(56)\end{array}$ & $\begin{array}{c}\text { A } \\
(45)\end{array}$ & $\begin{array}{c}W \\
(36)\end{array}$ & $\begin{array}{c}\text { Sp } \\
\text { (29) }\end{array}$ \\
\hline Thompsonula hyaenae & $\begin{array}{c}A \\
(23)\end{array}$ & $\begin{array}{c}\text { Su } \\
(18)\end{array}$ & $\begin{array}{c}W \\
(10)\end{array}$ & $\begin{array}{l}\mathrm{Sp} \\
(4)\end{array}$ \\
\hline Kiopsyllus constrictus & $\begin{array}{c}\mathrm{A} \\
(13)\end{array}$ & $\begin{array}{c}\mathrm{Su} \\
\text { (12) }\end{array}$ & $\begin{array}{c}W \\
\text { (11) }\end{array}$ & $\begin{array}{l}\mathrm{Sp} \\
(4)\end{array}$ \\
\hline Arenostella spinicauda & $\begin{array}{c}\mathrm{A} \\
(15)\end{array}$ & $\begin{array}{c}W \\
(10)\end{array}$ & $\begin{array}{l}\mathrm{Su} \\
(5)\end{array}$ & $\begin{array}{l}\mathrm{Sp} \\
(4)\end{array}$ \\
\hline Apodopsyllus unguiformis ( $p \leq 0.0001$ ) & $\begin{array}{c}\text { Su } \\
(15)\end{array}$ & $\begin{array}{c}\mathrm{Sp} \\
(12)\end{array}$ & $\begin{array}{c}\text { A } \\
\text { (6) }\end{array}$ & $\begin{array}{l}W \\
(1)\end{array}$ \\
\hline Halectinosoma winonae & $\begin{array}{c}\mathrm{Su} \\
(10)\end{array}$ & $\begin{array}{c}\text { A } \\
\text { (4) }\end{array}$ & $\begin{array}{l}\text { Sp } \\
\text { (3) }\end{array}$ & $\begin{array}{l}W \\
\text { (1) }\end{array}$ \\
\hline
\end{tabular}

\section{MUD SITE}

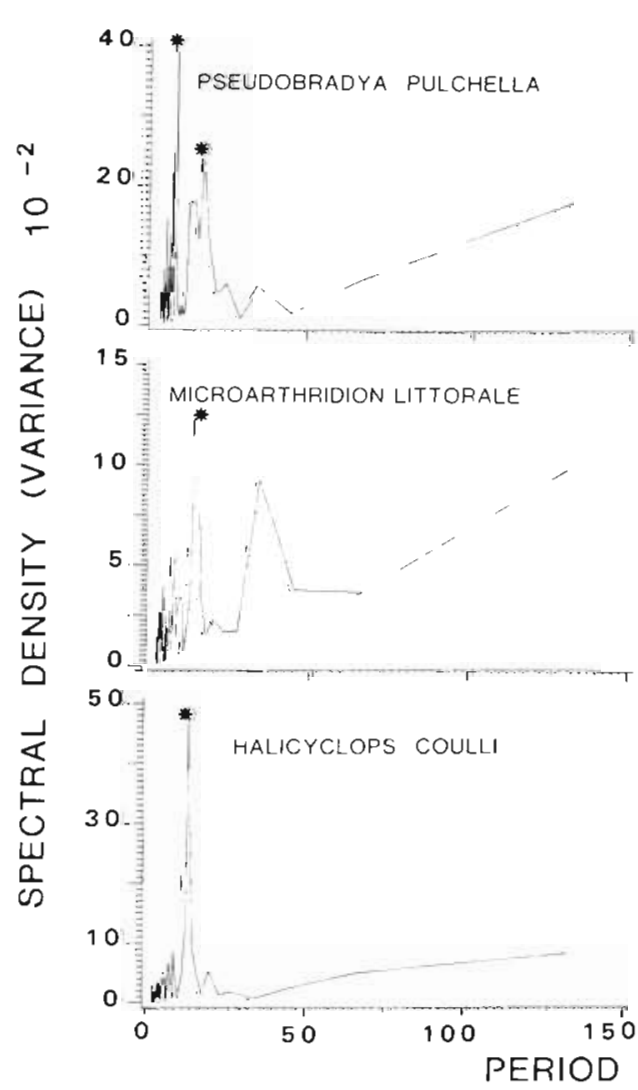

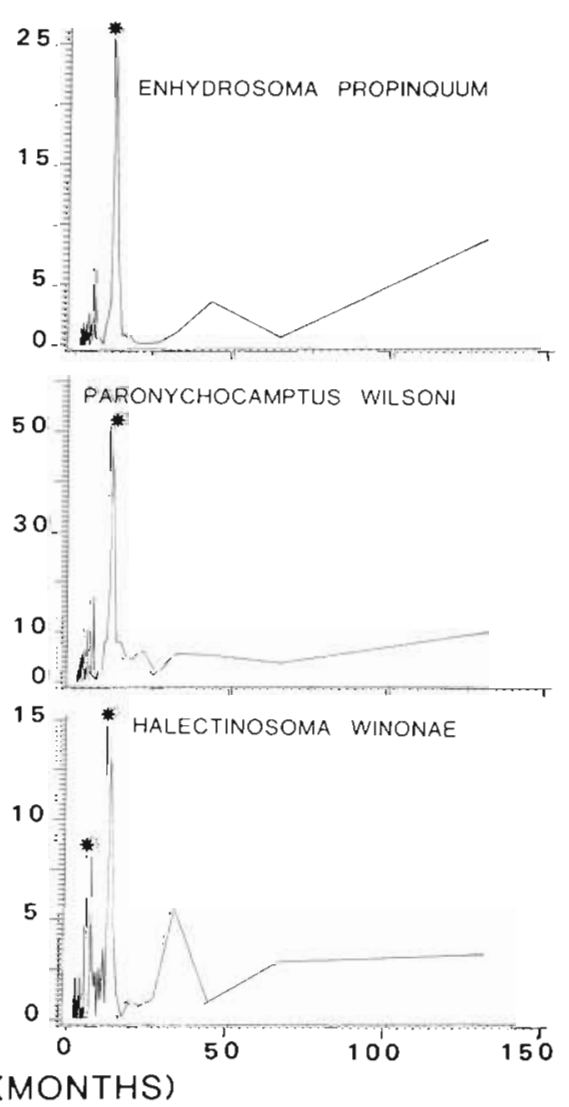

Fig. 6. Spectra of the species abundance at mud site. "Peaks that are significant (by Fishers $\mathrm{G}_{\text {crit }}$ statistic) and are not harmonics (see text) 
Fig. 7. Spectra of the species abundance at the sand site. - Peaks that are significant (by Fishers $G_{c n t}$ statistic) and are not harmonics (see text)

\section{SAND SITE}
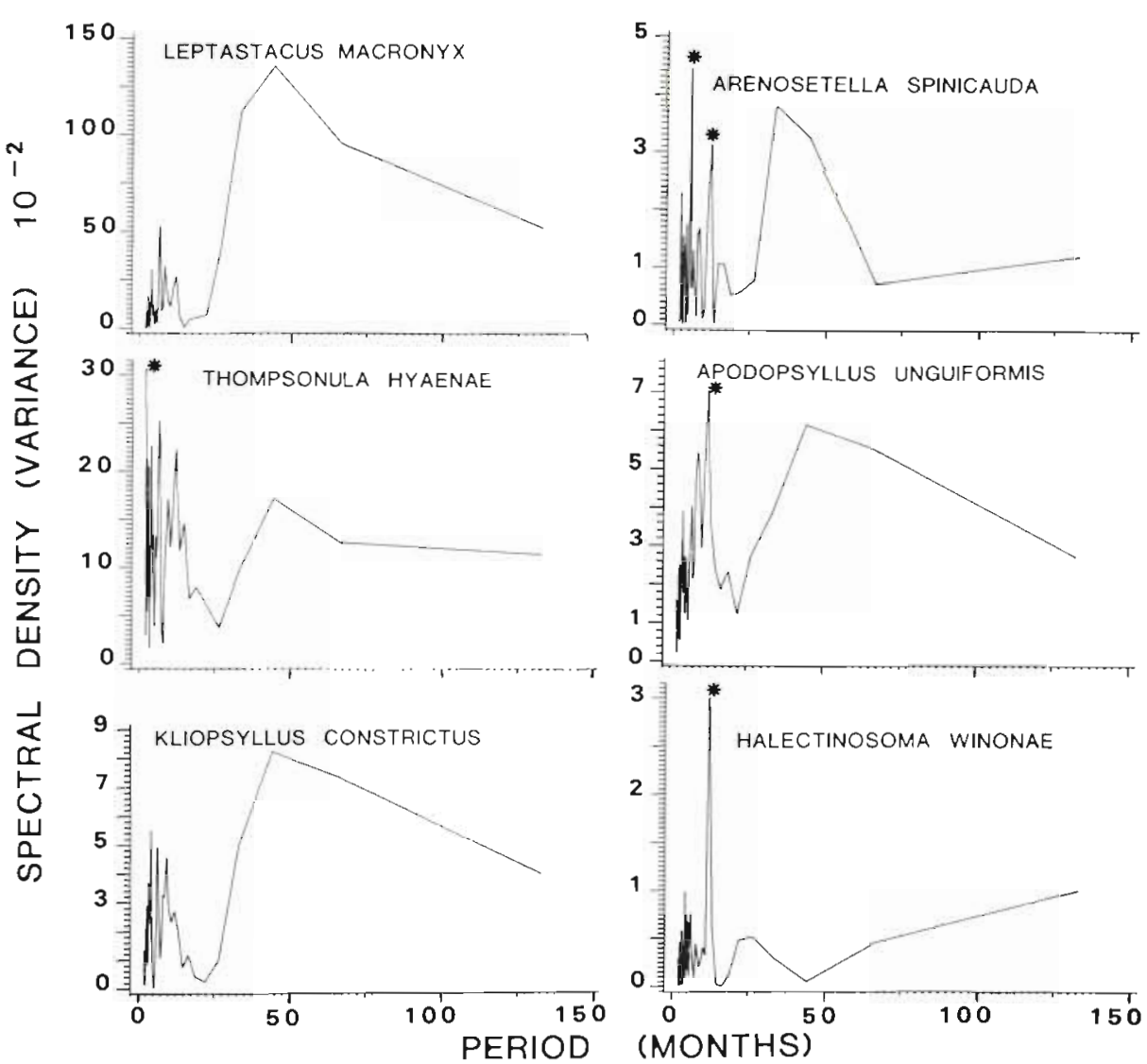

winonae; Paronychocamptus sp. is now $P$. wilsoni and Paracyclopina sp. is now Halicyclops coulli. The $2.3 \mathrm{yr}$ study indicated that Pseudobradya pulchella reached maximum abundance once a year in spring, whereas it is now clear that $P$. pulchella has a bi-modal distribution peaking in the spring and autumn (Fig. 4 \& 6; Table 3).

The seasonal patterns of the dominant sand species (note that the 3rd ranked species of Coull \& Vernberg, Hastigerella leptoderma, did not even rank in the top 6 for the entire $11 \mathrm{yr}$ ), is confounded by the general decline in copepod abundances. Leptastacus macronyx was not distinctly seasonal in the 2.3 yr study; nor was it during $11 \mathrm{yr}$ (Fig. 2 \& 7; Table 4). Thompsonula hyaenae was irregular the first 2.3 yr (Coull \& Vernberg 1975), but over the $11 \mathrm{yr}$ reached maximum abundance regularly in the autumn. Arenosetella spinicauda's seasonality over $11 \mathrm{yr}$ is essentially as reported by Coull \& Vernberg for 2.3 yr with peak abundance in autumn and winter. The other species, Apodopsyllus unguiformis, Halectinosoma winonae and Kliopsyllus constrictus, were not included in the Coull \& Vernberg report of sand dwelling species.

Halectinosoma winonae occurs at both sites, but reaches maximum abundance earlier (summer) at the sand site than at the mud site (autumn). This epibenthic, highly motile species may well enter the North Inlet system from the open ocean and migrate into the estuary. The sand site, just inside the inlet mouth, receives $H$. winonae first; it then, we suspect, migrates further into the system to the mud site, where it reaches maximum abundance in autumn.

Coull \& Vernberg (1975) also reported that the dominant species at each site (Leptastacus macronyx in sand; Microarthridion littorale in mud) were present and ovigerous all year round. Based on the $11 \mathrm{yr}$ data set, we cannot evaluate whether this would continue to be true for $L$. macronyx since this species has been eliminated at the sand site (Fig. 1). M. littorale is now the co-dominant at the mud site with Pseudobradya pulchella (Table 1). M. littorale was present on 165 of 170 sampling dates and had ovigerous females in the population $78.7 \%$ of the time. Thus, while not ovigerous all the time, as reported for the first $2.3 \mathrm{yr}$, it should still be considered a continuous breeder sensu Hicks (1979). The other dominant species at each site had discrete breeding periods coinciding with their maximum abundance illustrated in Fig. 1 to 4 . Our inability to distinguish a peak in ovigerous female abundance preceding both a juvenile and total population 
abundance maximum for any species is due, we feel, to 2 factors. First, all the eggs of a female or a population do not hatch simultaneously nor is the development rate of individual juveniles from the same clutch synchronous after the eggs are hatched (Coull \& Dudley 1976). Thus hatching and development are spread out over some time period (days to weeks?). Secondly, our shortest sampling interval of $2 \mathrm{wk}$ in 1981-83 was not sufficient to distinguish either those species with protracted development or those with 2 or more cohorts within our sampling interval. Accurate determination of sequencing of life history stages would require many replicated short interval samples (daily to weekly). Since most harpacticoids progressively increase their stage duration during development, i.e. a proportionately greater part of the total development is spent in the latter stages (Hicks \& Coull 1983), and since cohorts are known to overlap in time (Fleeger 1979), it may well be impossible to accurately assess life history sequencing from even short interval field data. Lab rearings would be necessary.

\section{Long-term abundance}

The absence of any long-term period in individual species abundance at the mud site is indicative of the consistent seasonality inherent in this community. That no species has a period longer than $1 \mathrm{yr}$, and that 2 of the top 6 have 6 mo and 1 yr periods, allows accurate $( \pm 1 \mathrm{mo})$ prediction of when each species will be present. This regular, consistent pattern is not surprising. The relative constancy of the habitat has apparently allowed development of an assemblage well tuned to recurring environmental parameters; thus maintaining definitive seasonal suites of meiobenthic copepods.

At the sand site, there was also no long-term periodicity in any species (once the spurious harmonics from the spectral analysis were removed). This lack of long-term periodicity does not appear to be a function of distinct seasonality since seasonality was not marked at the sand site. Three of the 6 top species significantly declined in abundance over the $11 \mathrm{yr}$ : these 3, all interstitial, species have apparently had their preferred habitat (interstitial space) removed. The lack of long-term cycles is thus confounded at the sand site by a declining number of interstitial species and repeatable cyclicity in the epibenthic forms (Thompsonula hyaenae, Halectinosoma winonae, Fig. 5; Table 4). Regardless of the reasons, we can discern no long-term periodicity in abundance of any of the top 12 species (both sites).

Herman \& Heip (1983) reported on long-term trends (spectral analysis) for 3 species from a Belgian brack- ish water pond and found that 1 species had a significant periodicity of longer than $1 \mathrm{yr}$. They correlated the reported $3.5 \mathrm{yr}$ periodicity of Canuella perplexa to a $3.5 \mathrm{yr}$ cycle in ammonium concentration (it is not clear if this ammonium was in the overlying water or in the sediment) and speculated that since ammonium is an indicator of decomposition rate, it may be an important forcing function for $C$. perplexa abundance. Combining the Herman \& Heip (1983) data (3 species) with ours (12 species), only 1 (Canuella perplexa) of the 15 species monitored regularly over the long term has any long-term periodicity. That 14 of the 15 species have annual or no detectable cycles suggests that meiobenthic copepods harpacticoids primarily respond to shortterm (1 yr or less) seasonal events and because of this, long-term population cycles do not occur.

It appears that seasonality of individual species can be accurately determined in a sampling regime of much less than $11 \mathrm{yr}$. The patterns reported by Coull \& Vernberg (1975) on $2.3 \mathrm{yr}$ of this data set are essentially the same as those recorded over the 11 yr. Two $\mathrm{yr}$, with adequate sampling frequency and assuming no unusual climatic or perturbation events, appears sufficient to track seasonal patterns. Only with such a long-term data set as reported here, which shows repeatable year-to-year constancy could one verify such a statement. Additionally, while there were no long-term population cycles there were long-term trends in abundance, i.e. the disappearance of the interstitial species at the sand site which could not have been detected with only 2 to $3 \mathrm{yr}$ of sampling. Thus, the value of long-term research very much depends on the questions being asked. We are convinced that $2 \mathrm{yr}$ (one must at least replicate years) of technically accurate sampling and sorting should provide species seasonal patterns; patterns which seem to be the dominant cycling periodicity in harpacticoids. Definition of long-term trends and seasonal patterns obviously requires sampling on a longer time scale.

Acknowledgements. We thank John W. Fleeger, Richard V. Levy, Brian M. Marcotte, and Jean P. Sikora for sorting samples: Richard A. Eskin and Donald G. Edwards for assistance in data analysis; and Roberta McCutchen for sample collection the last 2 yr. Richard A. Eskin, Robert J. Feller, Mark Luckenbach, John H. Tietjen, and Richard M. Warwick provided constructive criticisms on earlier drafts of this manuscript. This research was supported by the Biological Oceanography Section of the National Science Foundation through grants DES 7201573, OCE 7617584, OCE 7809450, OCE 8007968 and OCE 838114 (B. C. Coull, principal investigator) and the LTER Program of the Ecosystems section of NSF. Grant DEB 8012165 (F. J. Vernberg, principal investigator) 


\section{LITERATURE CITED}

Coull, B. C. (1985a). The use of long-term biological data to generate testable hypotheses. Estuaries 8: 84-92

Coull. B. C. (1985b). Long-term variability of estuarine meiobenthos: an 11 year study. Mar. Ecol. Prog. Ser. 24: 205-218

Coull, B. C., Dudley, B. W. (1976). Delayed naupliar development of meiobenthic copepods. Biol. Bull. mar. biol. Lab., Woods Hole 150: 38-46

Coull, B. C., Fleeger, J. W. (1977). Long-term temporal variation and community dynamics of meiobenthic copepods. Ecology 58: 1136-1143

Coull, B. C., Vernberg, W. B. (1975). Reproductive periodicity of meiobenthic copepods: seasonal or continuous? Mar. Biol. 32: 289-293

Fleeger, J. W. (1979). Population dynamics of three estuarine meiobenthic harpacticoids (Copepoda) in South Carolina. Mar. Biol. 52: 147-156

Heip, C. (1980). The influence of competition and predation on production of meiobenthic copepods. In: Tenore, K. R.,
Coull, B. C. (ed.) Marine benthic dynamics. University of South Carolina Press, Columbia, S.C., p. 167-177

Herman, P. M. J., Heip, C. (1983). Long-term dynamics of meiobenthic populations. Oceanologica Acta 1983: 109-112

Hicks, G. R. F. (1979). Pattern and strategy in the reproductive cycles of benthic harpacticoid copepods. In: Naylor, E., Hartnoll, R. G. (ed.) Cyclic phenomena in marine plants and animals. Pergamon Press, Oxford, p. 139-147

Hicks, G. R. F., Coull, B. C. (1983). The ecology of marine meiobenthic harpacticoid copepods. Oceanogr. mar. biol. A. Rev. 21: 67-125

deJonge, V. N., Bouman, L. A. (1977). A simple density separation technique for quantitative isolation of meiobenthos using the colloidal silica Ludox-TM. Mar. Biol. 42: 143-148

SAS Institute Inc. (1982). SAS user's guide: statistics, $1982 \mathrm{ed.}$ SAS Institute Inc., Cary, N.C.

Wieser, W. (1960). Benthic studies in Buzzards Bay II. The meiofauna. Limnol. Oceanogr. 5: 121-137

This paper was presented by Professor K. R. Tenore; it was accepted for printing on May 10, 1985 